\title{
Correspondence
}

\section{A review of finite-element modelling in snow mechanics}

The finite-element method (FEM) is one of the main numerical analysis methods in continuum mechanics and mechanics of solids (Huebner and others, 2001). Through mesh discretization of a given continuous domain into a finite number of sub-domains, or elements, the method finds approximate solutions to sets of simultaneous partial differential equations, which express the behavior of the elements and the entire system. For decades this methodology has played an accelerated role in mechanical engineering, structural analysis and, in particular, snow mechanics. To the best of our knowledge, the application of finite-element analysis in snow mechanics has never been summarized. Therefore, in this correspondence we provide a table with a detailed review of the main FEM studies on snow mechanics performed from 1971 to 2012 (40 papers), for facilitating comparison between different mechanical approaches, outlining numerical recipes and for future reference. We believe that this kind of compact review in a tabulated form will produce a snapshot of the state of the art, and thus become an appropriate, timely and beneficial reference for any relevant follow-up research, including, for example, not only snow avalanche questions, but also modeling of snow microstructure and tire-snow interaction. To that end, this correspondence is organized according to the following structure. Table 1 includes all essential information about previously published FEM studies originally developed to investigate stresses in snow with all corresponding mechanical and numerical parameters. Columns in Table 1 provide references to particular studies, placed in chronological order. Rows correspond to the main model parameters and other details of each considered case.

In order to give an overview of the studies covered by this review, we briefly summarize them below. Previously considered physical and engineering problems in snow mechanics can be roughly separated into several major categories, namely:

state of strain and stress in snowpack on slope, snow creep and compaction (Smith and others, 1971; Smith, 1972; Curtis and Smith, 1974; Smith and Curtis, 1975; Lang and Sommerfeld, 1977; Johnson, 1998; Bartelt and Christen, 1999; Bartelt and others, 2000; Teufelsbauer, 2009, 2011);

influence of snow weak layer and subcritical weak spots on the mechanical state of snowpack and slab avalanche release (McClung, 1979; Singh, 1980; Bader and Salm, 1990; Bartelt and Christen, 1999; Stoffel and Bartelt, 2003; Stoffel, 2005; Gaume and others, 2011, 2012);

skier loadings on inclined snowpack (Schweizer, 1993; Wilson and others, 1999; Jones and others, 2006; Habermann and others, 2008; Mahajan and others, 2010);

shock loading and explosive loading on snowpack (Johnson and others, 1993; Miller and others, 2011);

reproduction of mechanical experiments for studying fundamental rheological properties of snow (Mohamed and others, 1993; Meschke and others, 1996; Jamieson and Johnston, 2001; Haehnel and Shoop, 2004; Cresseri and Jommi, 2005; Cresseri and others, 2010);

forces exerted by snow cover on avalanche defense structures (Bartelt and Christen, 1999; Bartelt and others, 2000; Stoffel, 2005; Teufelsbauer, 2011);

fracture properties of snow and snow slabs, crack propagation (Bažant and others, 2003; Mahajan and Senthil, 2004; Stoffel, 2005; Sigrist and others, 2006; Sigrist and Schweizer, 2007; Heierli and others, 2008; Mahajan and Joshi, 2008);

tire/wheel-snow interaction (Haehnel and Shoop, 2004; Lee, 2009);

microstructure studies of snow volume obtained from Xray microtomography (Pieritz and others, 2004; Schneebeli, 2004; Srivastava and others, 2010; Theile, 2010; Hagenmuller, 2011).

We have omitted some studies from Table 1 because sufficient detail was not available to us (e.g. Navarre and Desrues, 1980; Singh, 1980). Others are omitted because they did not focus purely on mechanics; for example, some studies using FEM for snow or firn studies were mainly dedicated to heat transfer (at the microstructural level or at the snow-permafrost boundary), air ventilation within pore space, water infiltration or metamorphism (Christon and others, 1994; Tseng and others, 1994; Meussen and others, 1999; Phillips and others, 2000; Pielmeier and others, 2001; Albert, 2002; Bartelt and others, 2004; Kaempfer and others, 2005). Still others focused on the transition from solid to fluid (Daudon and Dufour, 2011) or the phase-tracking snow microstructure model (Slaughter and Zabaras, 2012). Finally, FEM papers on tire-snow interaction may be found in references within Haehnel and Shoop (2004) and Lee (2009).

We hope that the papers collected in this review will serve to facilitate comparison between and assimilation of different mechanical approaches or numerical recipes, and that they will be useful for solving the many remaining problems.

\section{ACKNOWLEDGEMENTS}

The research leading to these results has received funding from the International Affairs Directorate of IRSTEA (former name 'Cemagref'), INTERREG ALCOTRA $\left(\mathrm{MAP}^{3}\right)$, and from the People Programme (Marie Curie Actions) of the European Union's Seventh Framework Programme (FP7/20072013) under REA grant agreement No. 298672 (FP7PEOPLE-2011-IIF, 'TRIME'). E.A.P. is grateful for the support. We thank E.A. Hardwick for improving our English, and M. Schneebeli, P. Bartelt and T.H. Jacka for suggestions which gave birth to the final version of this correspondence.
IRSTEA (UR ETGR),

Saint-Martin-d'Hères, France

E-mail: evgeniy.podolskiy@gmail.com
G. CHAMBON

M. NAAIM

J. GAUME
E.A. PODOLSKIY 


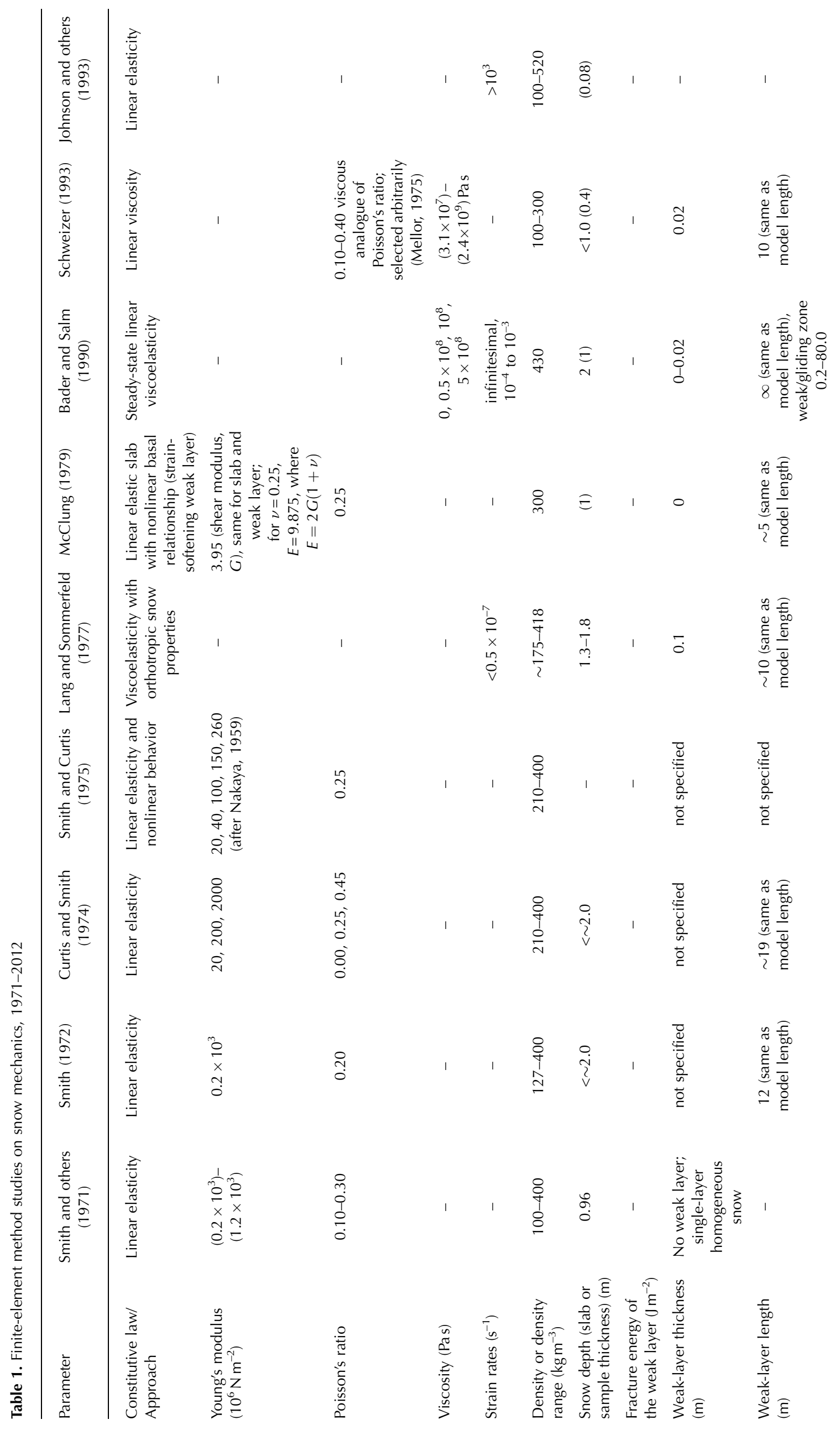




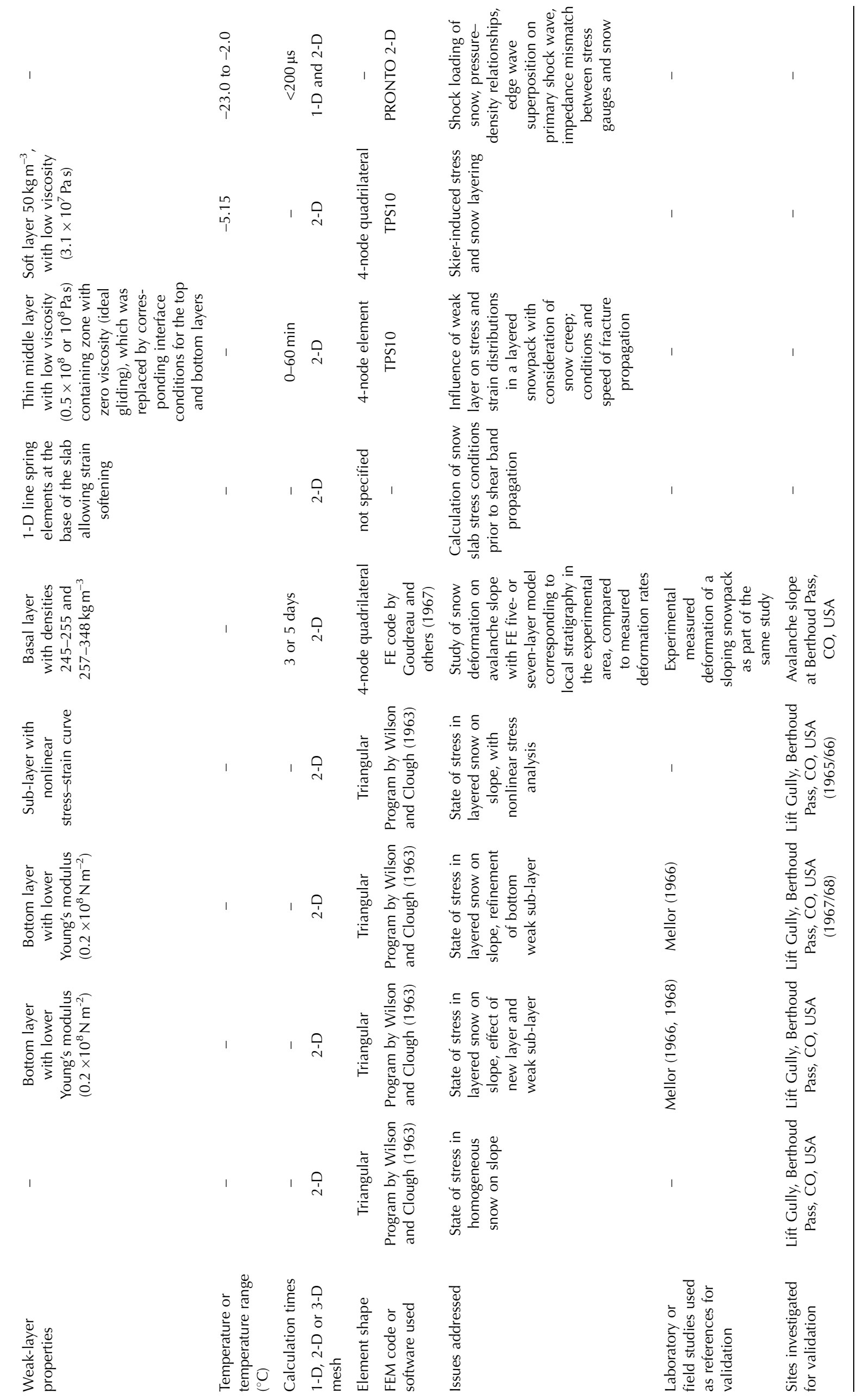




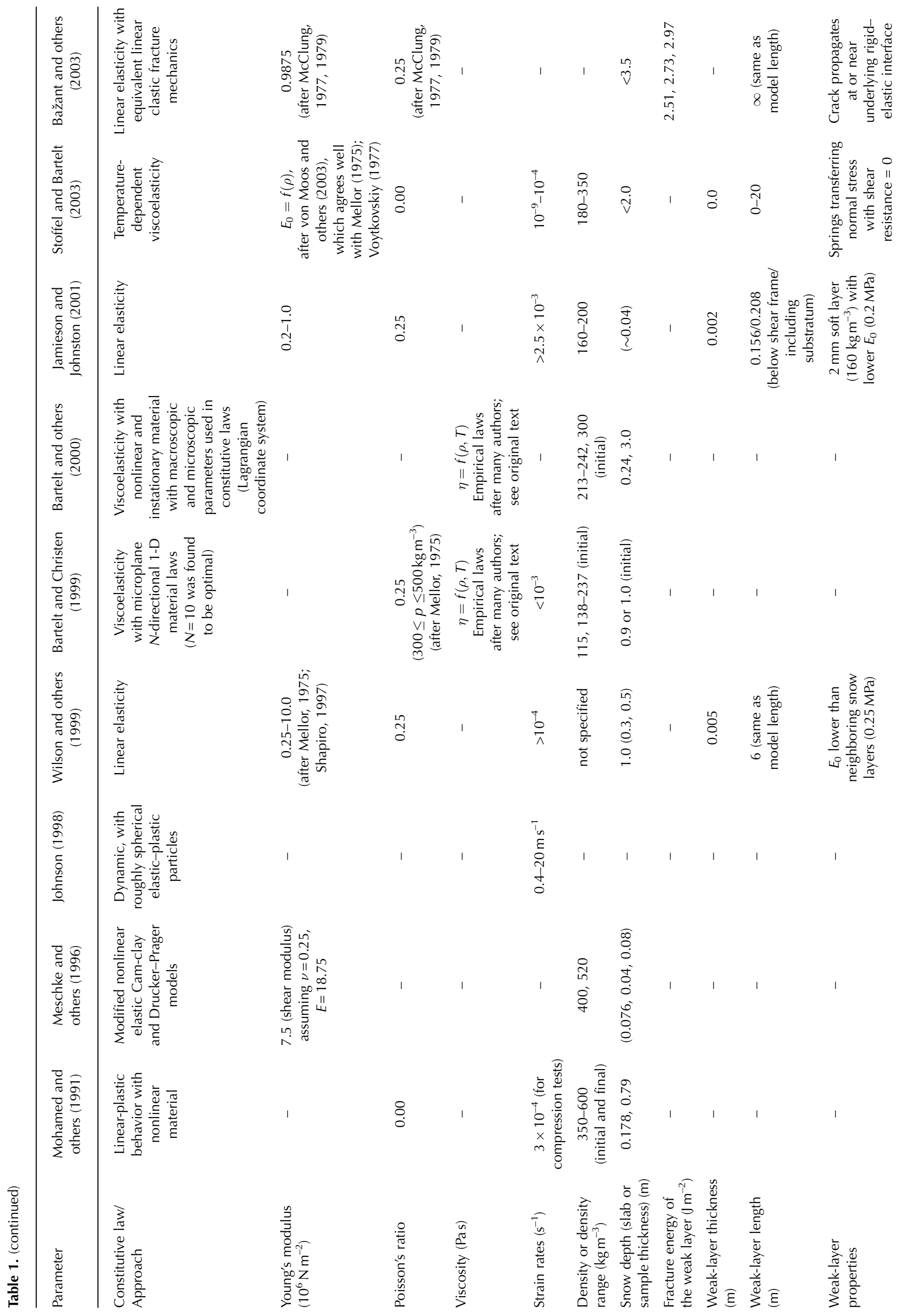




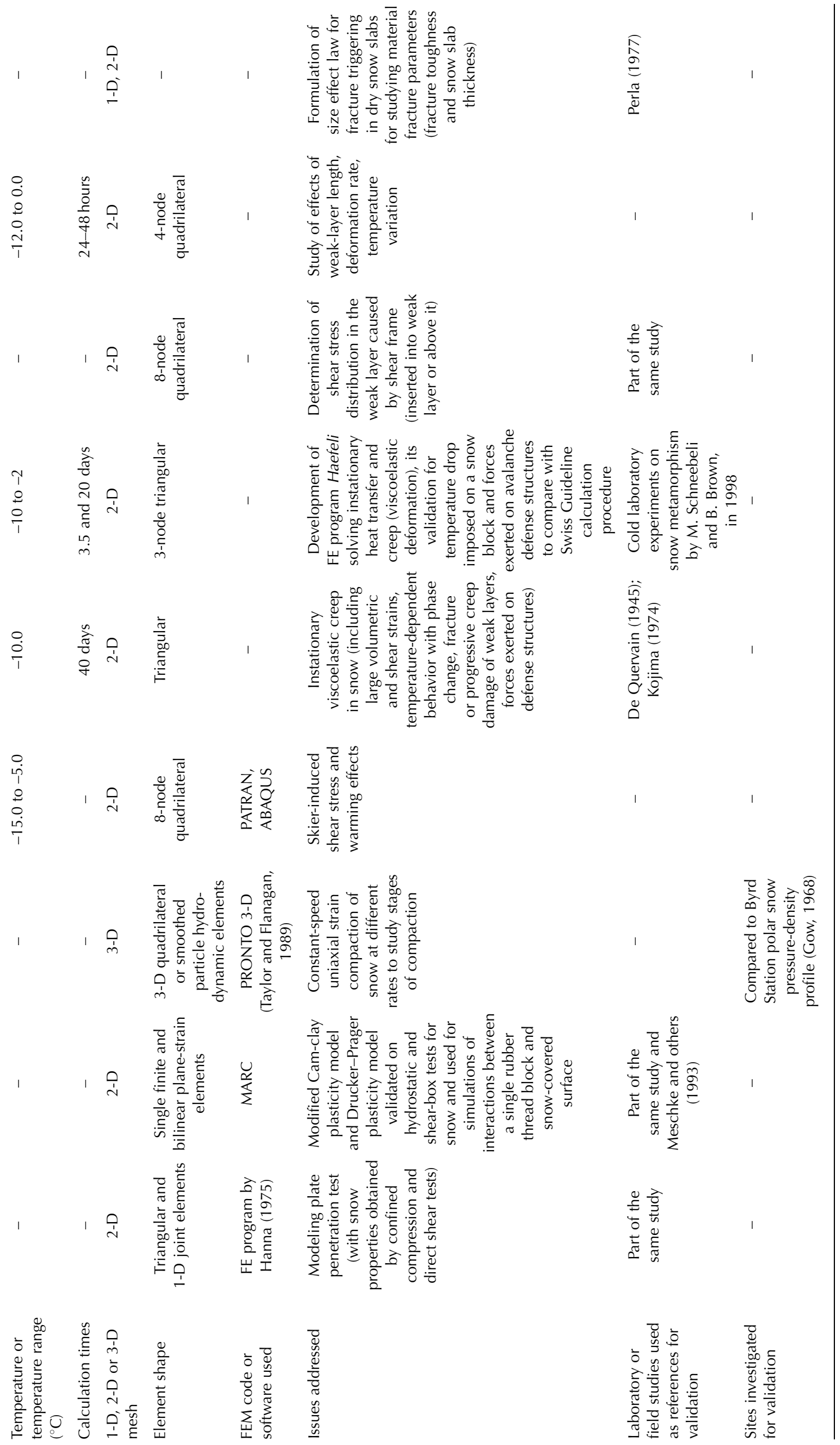




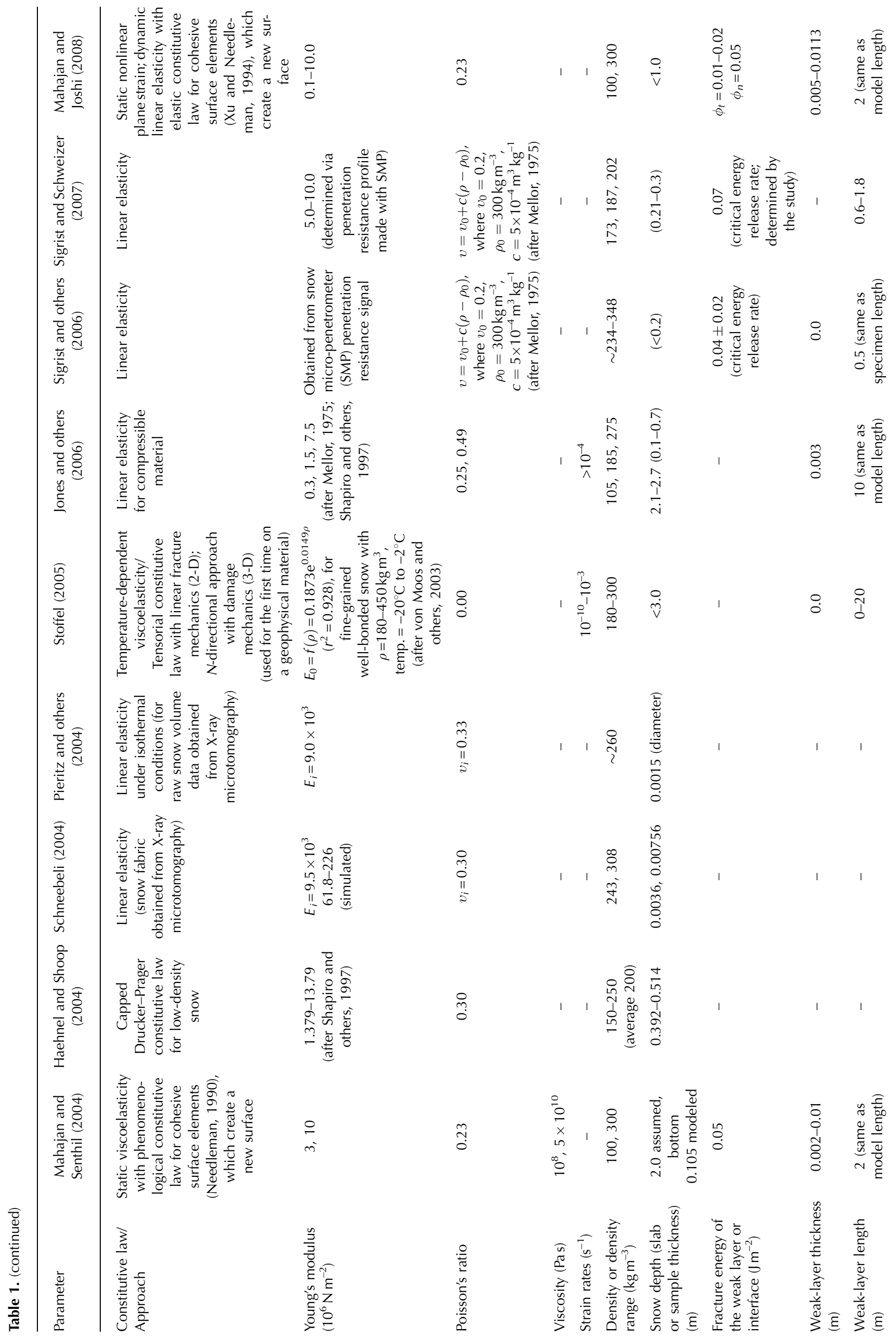




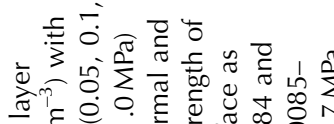

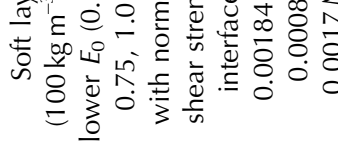

苟

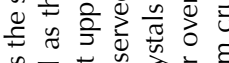

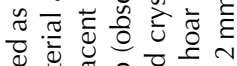

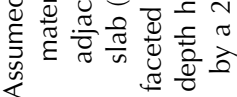

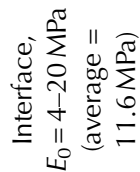

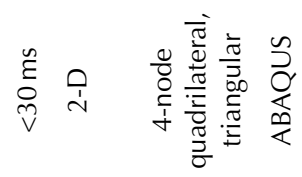

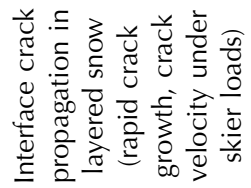

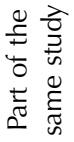

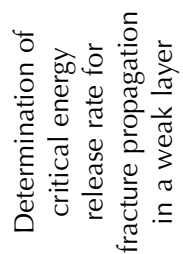

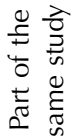

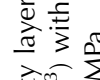

0
0
0

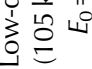

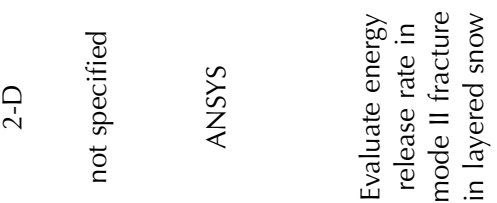

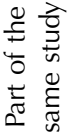

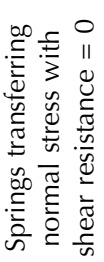

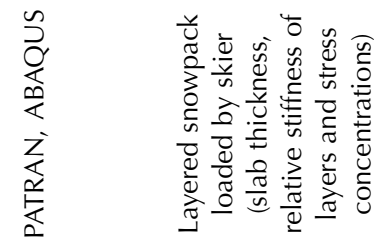

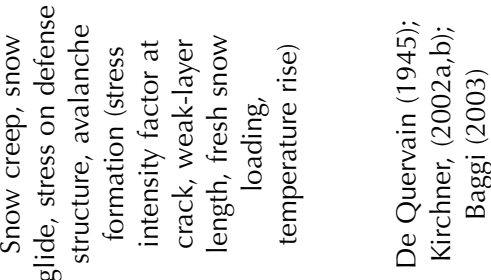

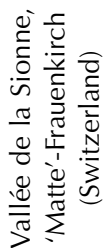

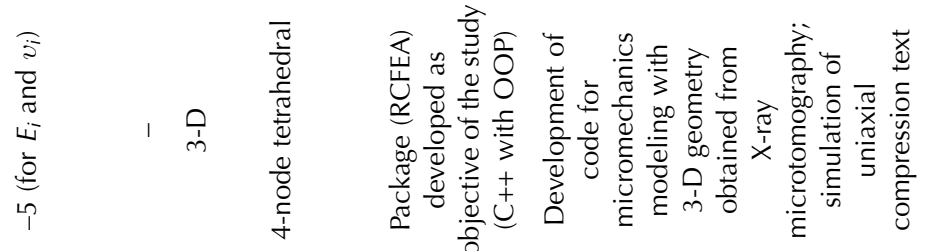

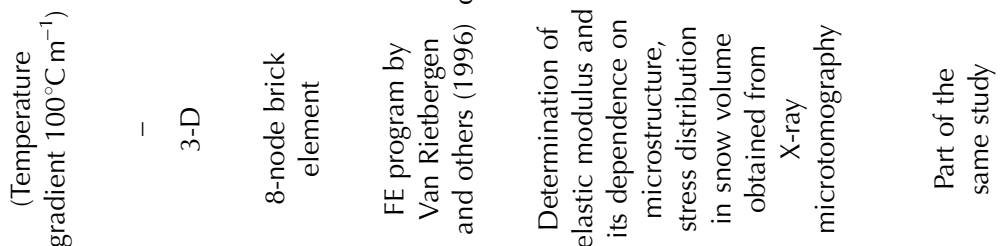

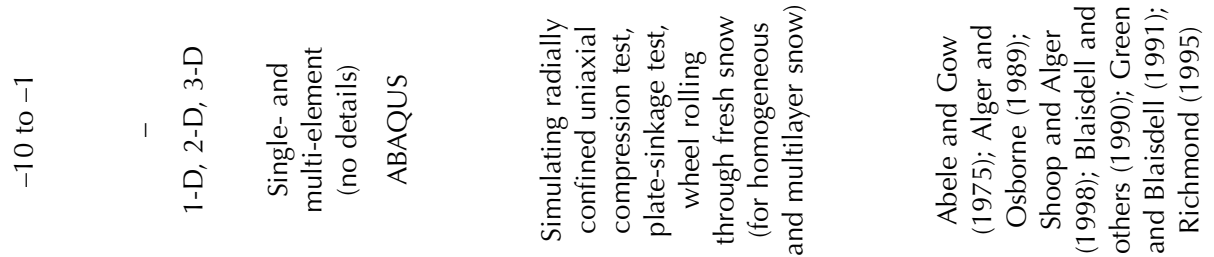

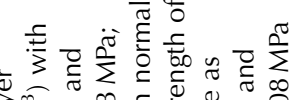

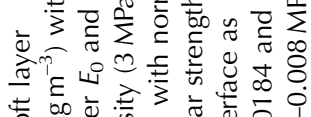

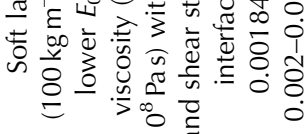

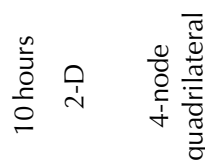

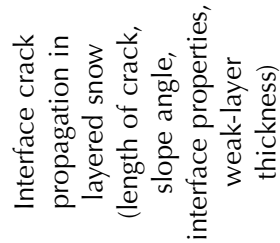

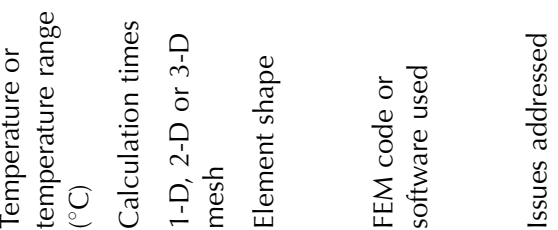

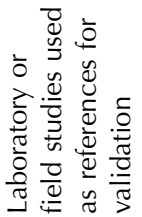

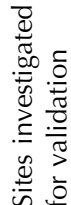




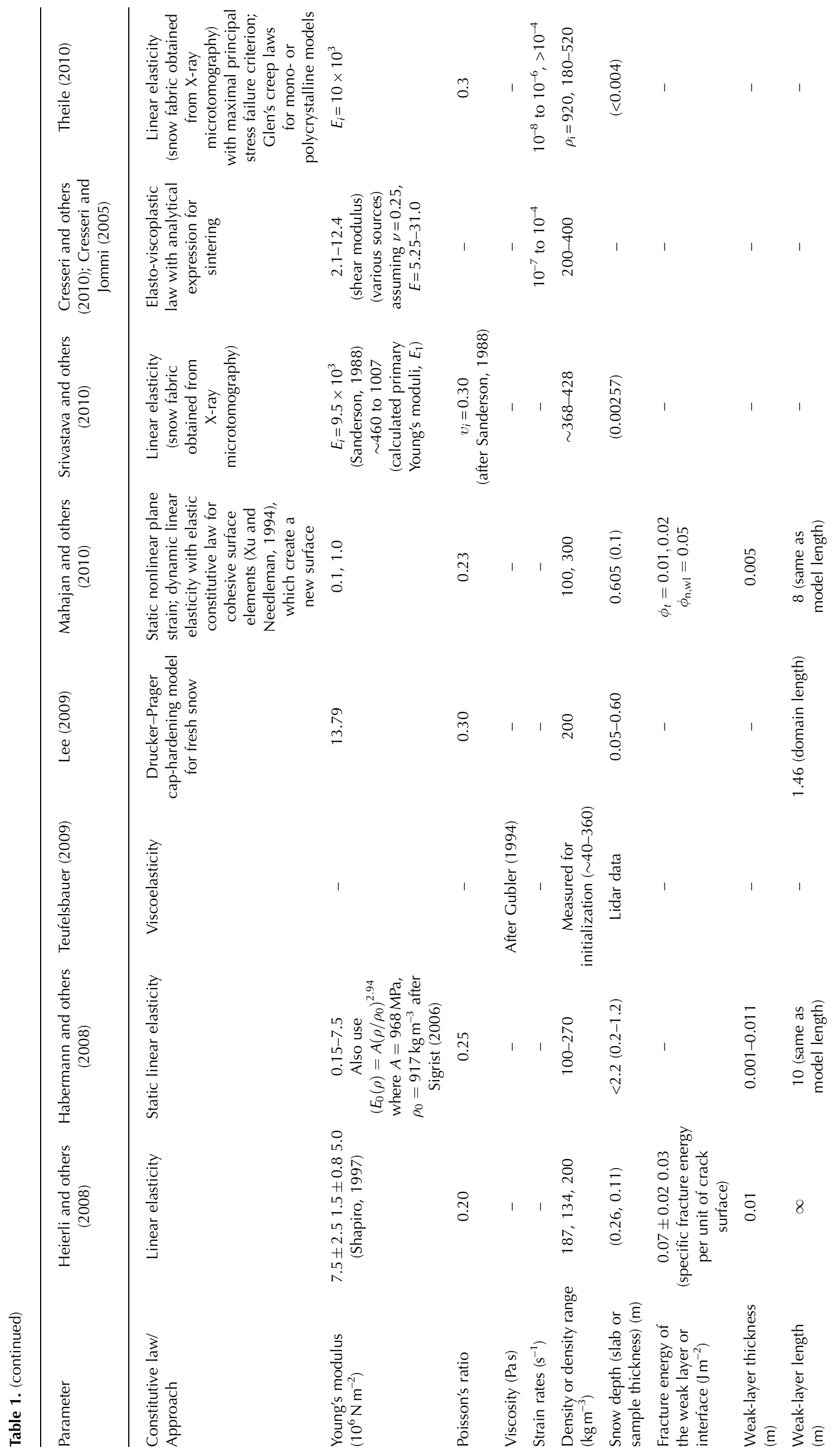




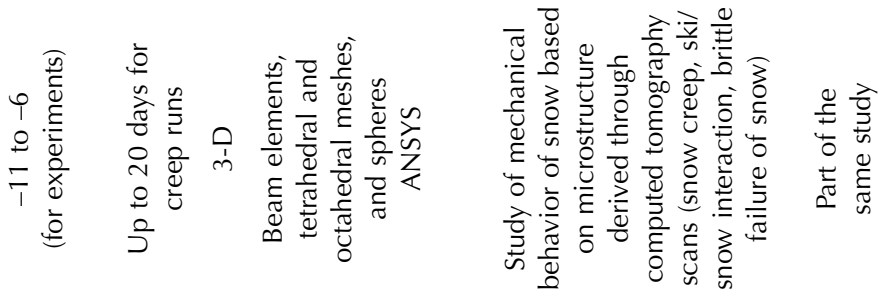

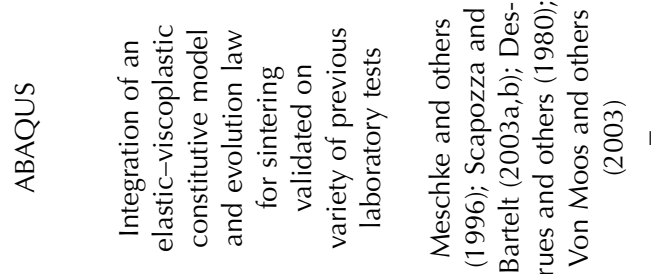

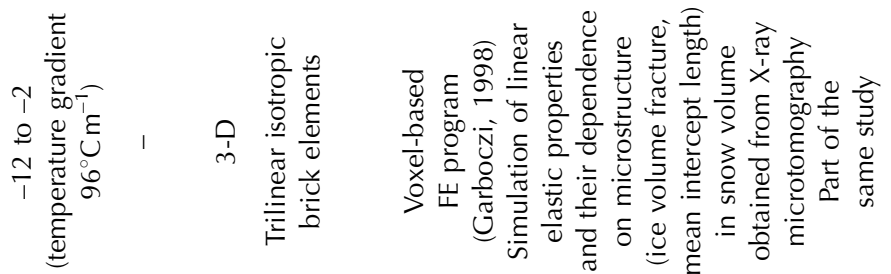

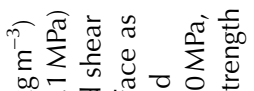

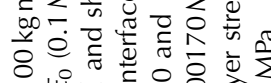

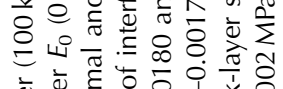

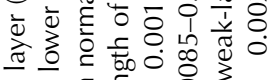

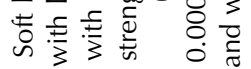

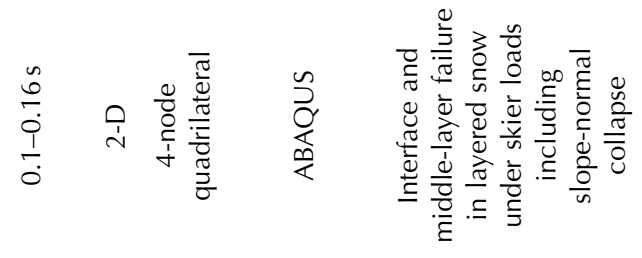

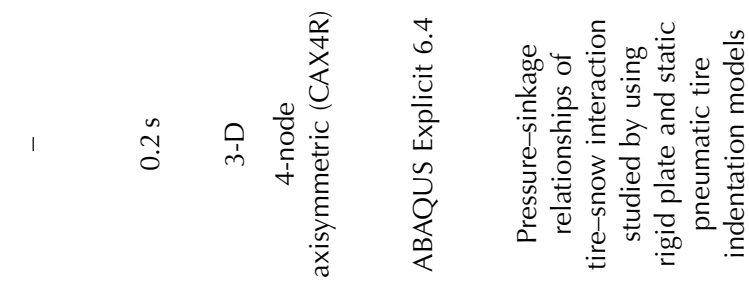

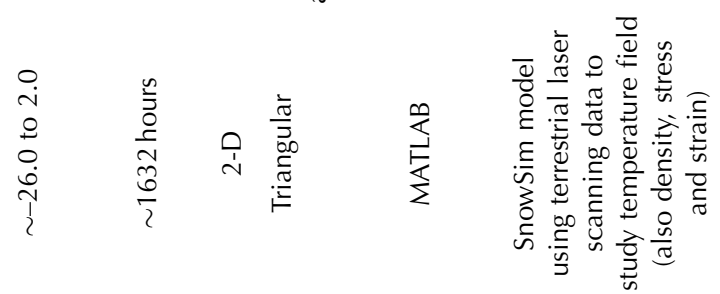

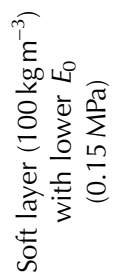

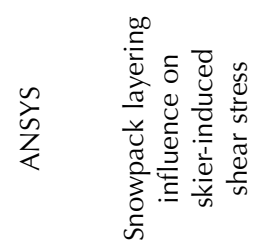

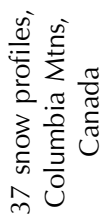

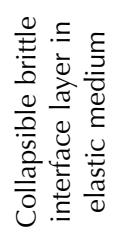

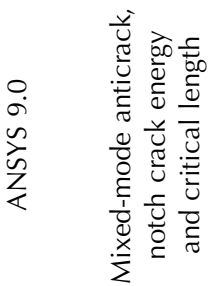

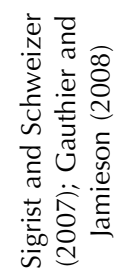




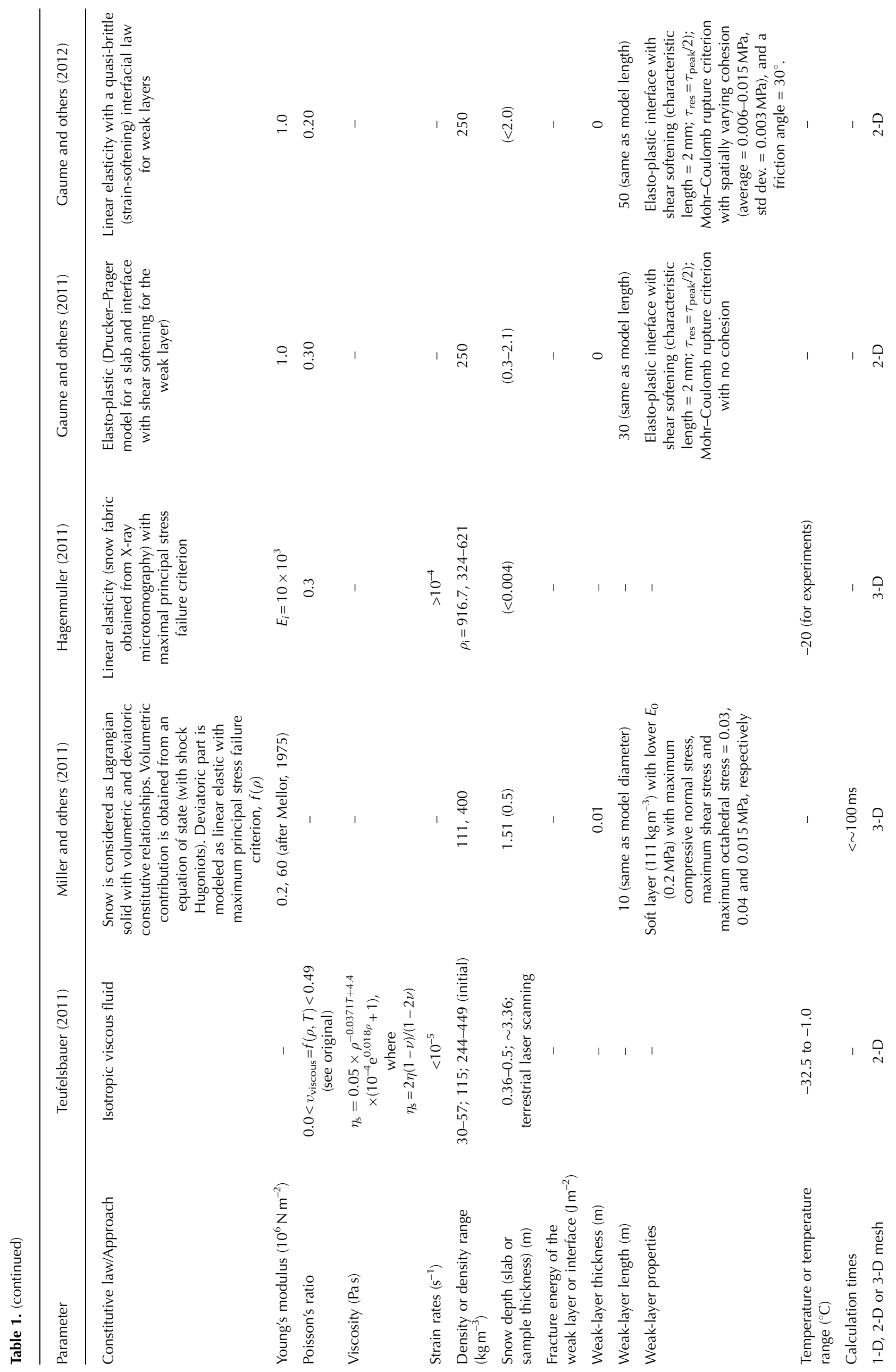



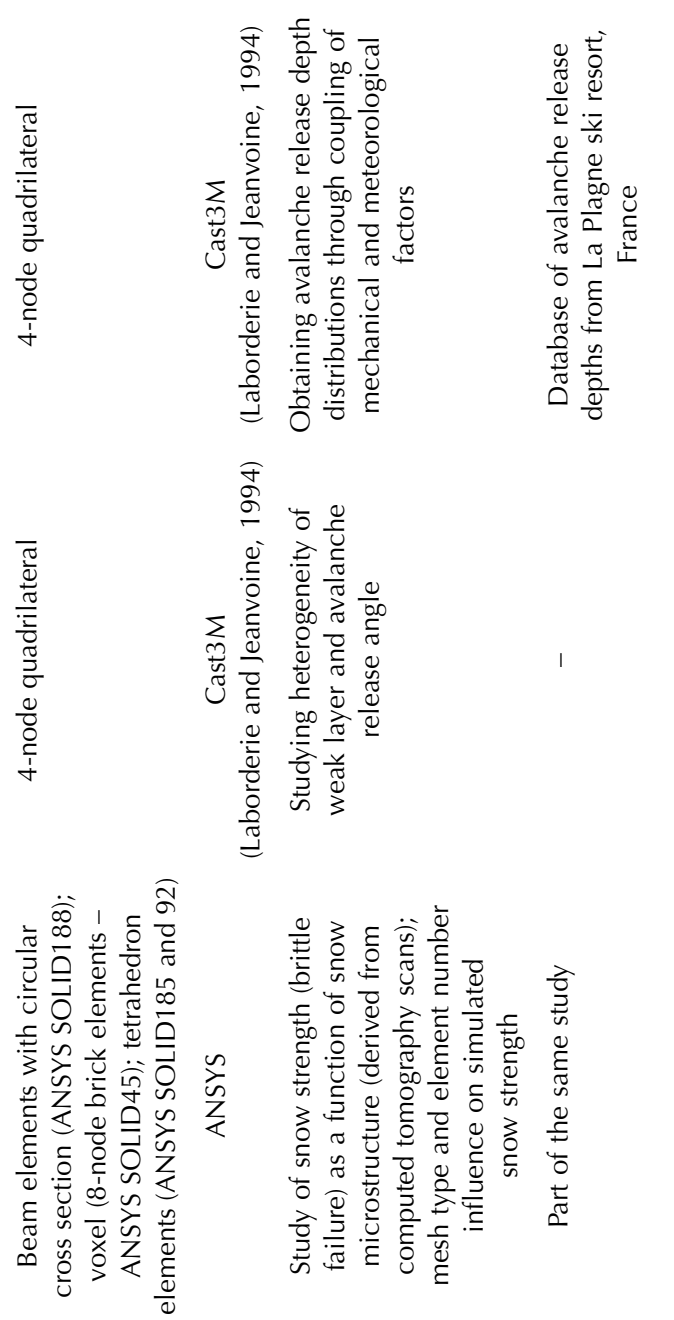

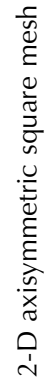
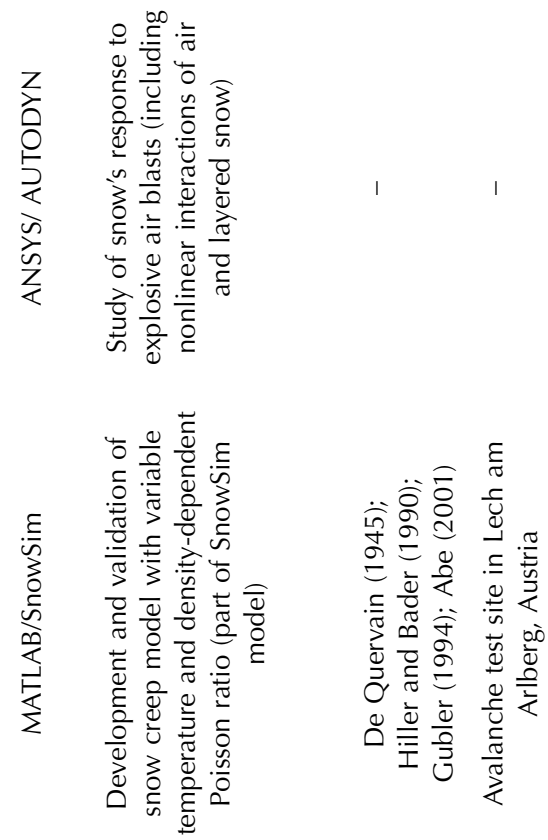

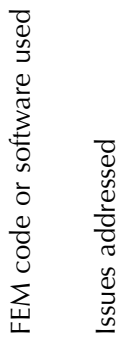

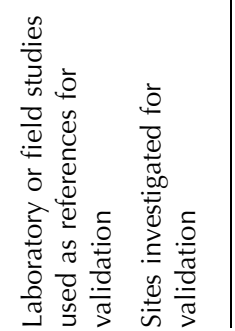

\section{REFERENCES}

Abe O (2001) Creep experiments and numerical simulations of very light artificial snowpacks. Ann. Glaciol., 32, 39-43 (doi: 10.3189/172756401781819201)

Abele G and Gow AJ (1975) Compressibility characteristics of undisturbed snow. CRREL Rep. 336

Albert MR (2002) Effects of snow and firn ventilation on sublimation rates. Ann. Glaciol., 35, 52-56 (doi: 10.3189/ 172756402781817194)

Alger R and Osborne M (1989) Snow characterization field data collection results. (Final Report no. ACA89-85-K-002) Keweenaw Research Center, Michigan Technological University, Houghton, MI

Bader HP and Salm B (1990) On the mechanics of snow slab release. Cold Reg. Sci. Technol., 17(3), 287-300 (doi: 10.1016/ S0165-232X(05)80007-2)

Baggi S (2003) Auswergung von Gleitschneebewegung und Schneedruckmessungen im SLF-Versuchsfeld 'Matte'-Frauenkirch $(1700 \mu \mathrm{M}) /$ Davos, GR. (Interner Bericht) WSL-Institut für Schnee- und Lawinenforschung (SLF), Davos

Bartelt P and Christen M (1999) A computational procedure for instationary temperature-dependent snow creep. In Hutter K, Wang $\mathrm{Y}$ and Beer $\mathrm{H}$ eds. Advances in cold-region thermal engineering and sciences: technological, environmental, and climatological impact. (Lecture Notes in Physics 533) SpringerVerlag, Berlin, 367-386

Bartelt P, Christen M and Wittwer S (2000) Program HAEFELI - twodimensional numerical simulation of the creeping deformation and temperature distribution in a phase changing snowpack. In Hjorth-Hansen E, Holand I, Løset S and Norem H eds. Snow Engineering: Recent Advances and Developments. Proceedings of the 4th International Conference on Snow Engineering, 19-21 June, 2000, Trondheim, Norway. A.A. Balkema, Rotterdam, 13-22

Bartelt P, Buser $\mathrm{O}$ and Sokratov S (2004) A nonequilibrium treatment of heat and mass transfer in alpine snowcovers. Cold Reg. Sci. Technol., 39(2-3), 219-242 (doi: 10.1002/10991085(20000615)14:8)

Bažant ZP, Zi G and McClung D (2003) Size effect law and fracture mechanics of the triggering of dry snow slab avalanches. J. Geophys. Res., 108(B2), 2119 (doi: 10.1029/2002JB001884)

Blaisdell GL, Richmond PW, Shoop SA, Green CE and Alger RG (1990) Wheels and tracks in snow: validation study of the CRREL shallow snow mobility model. CRREL Rep. 90-9

Christon M, Burns PJ and Somerfeld RA (1994) Quasi-steady temperature gradient metamorphism in idealized, dry snow. Num. Heat Trans. A, 25(3), 259-278 (doi: 10.1080/ 10407789408955948)

Cresseri S and Jommi C (2005) Snow as an elastic viscoplastic bonded continuum: a modelling approach. Riv. Ital. Geotec. 4, 43-58

Cresseri S, Genna F and Jommi C (2010) Numerical integration of an elastic-viscoplastic constitutive model for dry metamorphosed snow. Int. J. Num. Anal. Meth. Geomech., 34(12), 1271-1296 (doi: 10.1002/nag.864)

Curtis JO and Smith FW (1974) Material property and boundary condition effects on stresses in avalanche snow-packs. J. Glaciol., 13(67), 99-108

Daudon D and Dufour F (2011) Numerical modeling of dense snow rheology by means of the FEM with Lagrangian integration points. In Micro-dynamics of ice: papers from the Conference on Ice Deformation: From the Model Material to Ice in Natural Environments (Micro-DICE), 7-9 November 2011, Grenoble, France. [Abstract]

De Quervain MR (1945) Die Setzung der Schneedecke. (Intern. Ber. 11) Eidgenössisches Institut für Schnee- und Lawinenforschung (SLF), Davos

Desrues J, Darve F, Flavigny E, Navarre JP and Taillefer A (1980) An incremental formulation of constitutive equations for deposited snow. J. Glaciol., 25(92), 289-307 
Garboczi EJ (1998) Finite element and finite difference programs for computing the linear electric and elastic properties of digital images of random materials. (NIST Internal Report 6269) National Institute of Standards and Technology, Gaithersburgh, MD

Gaume J, Chambon G, Naaim M and Eckert N (2011) Influence of weak layer heterogeneity on slab avalanche release using a finite element method. In Bonelli S, Dascalu C and Nicot F eds. Advances in Bifurcation and Degradation in Geomaterials: Proceedings of the 9th International Workshop on Bifurcation and Degradation in Geomaterials, 23-26 May 2011, Porquerolles Island, Provence, France. (Springer Series in Geomechanics and Geoengineering 11) Springer, Dordrecht, 261-266

Gaume J, Chambon G, Eckert N and Naaim M (2012) Relative influence of mechanical and meteorological factors on avalanche release depth distributions. Geophys. Res. Lett., 39(12), L12401 (doi: 10.1029/2012GL051917)

Gauthier D and Jamieson JB (2008) Evaluation of a prototype field test for fracture and failure propagation in weak snow pack layers. Cold Reg. Sci. Technol., 51(2-3), 87-97 (doi: 10.1016/ j.coldregions.2007.04.005)

Goudreau GL, Nickell RE and Dunham RS (1967) Plane and axisymmetric finite element analysis of locally orthotropic elastic solids and orthotropic shells. (Report No. UCB/SESM1967/15) Department of Civil Engineering, University of California, Berkeley, CA

Gow AJ (1968) Deep core studies of the accumulation and densification of snow at Byrd Station and Little America V, Antarctica. CRREL Res. Rep. 197.

Green CE and Blaisdell GL (1991) US Army wheeled versus tracked vehicle mobility performance test program. Report No. 2: Mobility in shallow snow. (Tech. Rep. GL-91-7) Waterways Experiment Station, US Army Corps of Engineers, Vicksburg, MS

Gubler H (1994) Physik von Schnee. Eidgenössisches Institut für Schnee- und Lawinenforschung (SLF), Davos

Habermann M, Schweizer J and Jamieson JB (2008) Influence of snowpack layering on human-triggered snow slab avalanche release. Cold Reg. Sci. Technol., 54(3), 176-182 (doi: 10.1016/ j.coldregions.2008.05.003)

Haehnel RB and Shoop SA (2004) A macroscale model for low density snow subjected to rapid loading. Cold Reg. Sci. Technol., 40(3), 193-211 (doi: 10.1016/j.coldregions.2004. 08.001)

Hagenmuller P (2011) Experiments and simulation of the brittle failure of snow. (MSC thesis, WSL Institute for Snow and Avalanche Research)

Hanna AW (1975) Finite element analysis of soil cutting and traction. (PhD thesis, McGill University)

Heierli J, Gumbsch P and Zaiser M (2008) Anticrack nucleation as triggering mechanism for snow slab avalanches. Science, 321(5886), 240-243 (doi: 10.1126/science.1153948)

Hiller M and Bader HP (1990) Schneedruck auf Stützwerke. (Intern. Ber. 660) Eidgenössisches Institut für Schnee- und Lawinenforschung (SLF), Davos

Huebner KH, Dewhirst DL, Smith DE and Byrom TG (2001) The finite element method for engineers, 4th edn. Wiley, New York

Jamieson B and Johnston CD (2001) Evaluation of the shear frame test for weak snowpack layers. Ann. Glaciol., 32, 59-69 (doi: 10.3189/172756401781819472)

Johnson JB (1998) A preliminary numerical investigation of the micromechanics of snow compaction. Ann. Glaciol., 26, 51-54

Johnson JB, Solie DJ, Brown JA and Gaffney ES (1993) Shock response of snow. J. Appl. Phys., 73(10), 4852-4861 (doi: $10.1063 / 1.353801$

Jones A, Jamieson B and Schweizer J (2006) The effect of slab and bed surface stiffness on the skier-induced shear stress in weak snowpack layers. In Gleason JA ed. Proceedings of the 2006 International Snow Science Workshop, 1-6 October 2006, Telluride, Colorado, USA. International Snow Science Workshop, 157-164
Kaempfer TU, Schneebeli M and Sokratov SA (2005) A microstructural approach to model heat transfer in snow. Geophys. Res. Lett., 32(21), L21503 (doi: 10.1029/2005GL023873)

Kirchner HOK, Michot G and Schweizer J (2002a) Fracture toughness of snow in shear and tension. Scripta Mater., 46(6), 425-429 (doi: 10.1016/S1359-6462(02)00007-6)

Kirchner H, Michot G and Schweizer J (2002b) Fracture toughness of snow in shear under friction. Phys. Rev. E, 66(2), 027103 (doi: 10.1103/PhysRevE.66.027103)

Kojima K (1974) A field experiment on the rate of densification of natural snow layers under low stress. IAHS Publ. 114 (Symposium at Grindelwald - Snow Mechanics), 298-308

Laborderie C and Jeanvoine E (1994) Beginning with Castem 2000. (Tech. Rep. DMT/94-356) Commissariat à l'Énergie Atomique, Paris

Lang TE and Sommerfeld RA (1977) The modeling and measurement of the deformation of a sloping snow-pack. J. Glaciol., 19(81), 153-163

Lee JH (2009) A new indentation model for snow. J. Terramech., 46(1), 1-13 (doi: 10.1016/j.jterra.2009.02.001)

Mahajan P and Joshi SK (2008) Modeling of interfacial crack velocities in snow. Cold Reg. Sci. Technol., 51(2-3), 98-111 (doi: 10.1016/j.coldregions.2007.05.008)

Mahajan P and Senthil S (2004) Cohesive element modeling of crack growth in a layered snowpack. Cold Reg. Sci. Technol., 40(1-2), 111-112 (doi: 10.1016/j.coldregions.2004.06.006)

Mahajan P, Kalakuntla R and Chandel C (2010) Numerical simulation of failure in a layered thin snowpack under skier load. Ann. Glaciol., 51(54), 169-175 (doi: 10.3189/ 172756410791386436)

McClung DM (1977) Direct simple shear tests on snow and their relation to slab avalanche formation. J. Glaciol., 19(81), 101-109

McClung DM (1979) Shear fracture precipitated by strain softening as a mechanism of dry slab avalanche release. J. Geophys. Res., 84(B7), 3519-3526 (doi: 10.1029/JB084iB07p03519)

Mellor M (1966) Snow mechanics. Appl. Mech. Rev., 19(5), 379-389

Mellor M (1968) Avalanches. CRREL Monogr. MIII-A3d

Mellor M (1975) A review of basic snow mechanics. IAHS Publ. 114 (Symposium at Grindelwald 1974 - Snow Mechanics), 251-291

Meschke G, Liu CH and Mang HA (1993) Mechanische Eigenschaften von Schnee und numerische Simulationen der Wechselwirkung zwischen Profilstollen und Schneefahrbahn. Zwischenbericht tiber das Forschungsprojekt: Untersuchung der Reifentraktions mechanismen auf schnee- bzw. eisbedeckten Fahrbahnen mittels FEM. (Teilschritt 111) Technische Universität Wien, Vienna

Meschke G, Liu C and Mang HA (1996) Large strain finite-element analysis of snow. J. Eng. Mech., 122(7), 591-602 (doi: 10.1061/ (ASCE)0733-9399(1996)122:7(591))

Meussen B, Mahrenholtz O and Oerter H (1999) Creep of polar firn. Cold Reg. Sci. Technol., 29(3), 177-200 (doi: 10.1016/ S0165-232X(99)00018-X)

Miller DA, Tichota RG and Adams EE (2011) An explicit numerical model for the study of snow's response to explosive air blast. Cold Reg. Sci. Technol., 69(2-3), 156-164 (doi: 10.1016/ j.coldregions.2011.08.004)

Mohamed AMO, Yong RN and Murcia AJ (1991) Evaluation of the performance of deep snowpack under compression loading using finite element analysis. J. Terrmech., 30(4), 219-257 (doi: 10.1016/0022-4898(93)90013-N)

Nakaya U (1959) Visco-elastic properties of snow and ice in the Greenland ice cap. SIPRE Res. Rep. 46

Navarre JP and Desrues J (1980) Finite-element analysis of snow on slopes. J. Glaciol., 26(94), 516

Needleman A (1990) An analysis of decohesion along an imperfect interface. Int. J. Frac., 42(1), 21-40 (doi: 10.1007/ BF00018611) 
Perla R (1977) Slab avalanche measurements. Can. Geotech. J., 14(2), 206-213

Phillips M, Bartelt P and Christen M (2000) Influences of avalanchedefence snow-supporting structures on ground temperature in Alpine permafrost terrain. Ann. Glaciol., 31, 422-426 (doi: 10.3189/172756400781820336)

Pielmeier C, Schneebeli M and Stucki T (2001) Snow texture: a comparison of empirical versus simulated texture index for Alpine snow. Ann. Glaciol., 32, 7-13 (doi: 10.3189/ 172756401781819715)

Pieritz RA, Brzoska JB, Flin F, Lesaffre B and Coléou C (2004) From snow $\mathrm{X}$-ray microtomograph raw volume data to micromechanics modeling: first results. Ann. Glaciol., 38, 52-58 (doi: 10.3189/172756404781815176)

Richmond PW (1995) Motion resistance of wheeled vehicles in snow. CRREL Res. Rep. 95-7.

Sanderson TJO (1988) Mechanical properties of ice: laboratory studies. In Sanderson TJO ed. Ice mechanics: risks to offshore structures. Graham and Trotman, London, 70-103

Scapozza C and Bartelt P (2003a) Triaxial tests on snow at low strain rate. Part II. Constitutive behaviour. J. Glaciol., 49(164), 91-101 (doi: 10.3189/172756503781830890)

Scapozza C and Bartelt P (2003b) The influence of temperature on the small-strain viscous deformation mechanics of snow: a comparison with polycrystalline ice. Ann. Glaciol., 37, 90-96 (doi: 10.3189/172756403781815410)

Schneebeli M (2004) Numerical simulation of elastic stress in the microstructure of snow. Ann. Glaciol., 38, 339-342 (doi: $10.3189 / 172756404781815284)$

Schweizer J (1993) The influence of the layered character of snow cover on the triggering of slab avalanches. Ann. Glaciol., 18, 193-198

Shapiro LH, Johnson JB, Sturm M and Blaisdell GL (1997) Snow mechanics: review of the state of knowledge and applications. CRREL Rep. 97-3.

Shoop S and Alger R (1998) Snow deformation beneath a vertically loaded plate: formation of pressure bulb with limited lateral displacement. In Newcomb DE ed. Cold Regions Impact on Civil Works: Proceedings of the 9th International Conference on Cold Regions Engineering, 27-30 September 1998, Duluth, Minnesota. American Society of Civil Engineers, Reston, VA, $143-150$

Sigrist C (2006) Measurement of fracture mechanical properties of snow and application to dry snow slab avalanche release. $(\mathrm{PhD}$ thesis, ETH Zürich)

Sigrist C and Schweizer J (2007) Critical energy release rates of weak snowpack layers determined in field experiments. Geophys. Res. Lett., 34(3), L03502 (doi: 10.1029/2006GL028576)

Sigrist C, Schweizer J, Schindler H-J and Dual J (2006) The energy release rate of mode II fractures in layered snow samples. Int. J. Frac., 139(3-4), 461-475 (doi: 10.1007/s10704-006-6580-9)

Singh H (1980) A finite element model for the prediction of dry slab avalanches. (PhD thesis, Colorado State University)

Slaughter AE and Zabaras N (2012) A phase-tracking snow microstructure model. In Proceedings of the International Snow Science Workshop, 16-21 September 2012, Anchorage, Alaska.
International Snow Science Workshop, 395-397 http://arc.lib.montana.edu/snow-science/item/1739

Smith FW (1972) Elastic stresses in layered snow packs. J. Glaciol., 11(63), 407-414

Smith FW and Curtis JO (1975) Stress analysis and failure prediction in avalanche snowpacks. IAHS Publ. 114 (Symposium at Grindelwald 1974 - Snow Mechanics), 332-340

Smith FW, Sommerfeld RA and Bailey RO (1971) Finite-element stress analysis of avalanche snowpacks. J. Glaciol., 10(60), 401-405

Srivastava PK, Mahajan P, Satyawali PK and Kumar V (2010) Observation of temperature gradient metamorphism in snow by $\mathrm{X}$-ray computed microtomography: measurement of microstructure parameters and simulation of linear elastic properties. Ann. Glaciol., 51(54), 73-82 (doi: 10.3189/172756410791386571)

Stoffel M (2005) Numerical modelling of snow using finite elements. (PhD thesis, ETH Zürich)

Stoffel M and Bartelt P (2003) Modelling snow slab release using a temperature-dependent viscoelastic finite element model with weak layers. Surv. Geophys., 24(5-6), 417-430 (doi: 10.1023/ B:GEOP.0000006074.56474.43)

Taylor LM and Flanagan DP (1989) PRONTO 3D: a threedimensional transient solid dynamics program. (Sandia Report SAND87-1912.UC-32) Sandia National Laboratories, Albuquerque, NM

Teufelsbauer H (2009) Linking laser scanning to snowpack modeling: data processing and visualization. Comput. Geosci., 35(7), 1481-1490 (doi: 10.1016/j.cageo.2008.10.006)

Teufelsbauer H (2011) A two-dimensional snow creep model for alpine terrain. Natur. Hazards, 56(2), 481-497 (doi: 10.1007/ s11069-010-9515-8)

Theile T (2010) Three-dimensional structural image analysis and mechanics of snow. (Dr.-Ing. dissertation, Technischen Universität Dortmund)

Tseng P-H, Illangasekare TH and Meier MF (1994) A 2-D finite element method for water infiltration in a subfreezing snowpack with a moving surface boundary during melting. Adv. Water Resour., 17(4), 205-219 (doi: 10.1016/0309-1708(94)90001-9)

Van Rietbergen B, Weinans H, Huiskes R and Polman BJW (1996) Computational strategies for iterative solutions of large FEM applications employing voxel data. Int. J. Num. Meth. Eng., 39(16), 2743-2767 (doi: 10.1002/(SICl)1097-0207(19960830) 39:16<2743::AID-NME974>3.0.CO;2-A)

Von Moos M, Bartelt P, Zweidler A and Bleiker E (2003) Triaxial tests on snow at low strain rate. Part I. Experimental device. J. Glaciol., 49(164), 81-90 (doi: 10.3189/172756503781830881)

Voytkovskiy KF (1977) The mechanical properties of snow [transl. C.E. Bartelt]. Nauka, Moscow

Wilson EL and Clough RW (1963) Finite element analysis of twodimensional structures. (PhD thesis, University of California)

Wilson A, Schweizer J, Johnson CD and Jamieson JB (1999) Effects of surface warming of a dry snowpack. Cold Reg. Sci. Technol., 30(1-3), 59-65 (doi: 10.1016/S0165-232X(99)00014-2)

Xu X-P and Needleman A (1994) Numerical simulations of fast crack growth in brittle solids. J. Mech. Phys. Solids, 42(9), 1397-1434 (doi: 10.1016/0022-5096(94)90003-5) 